\title{
EWSR1/FLI1 Fusion Gene Type 2
}

National Cancer Institute

\section{Source}

National Cancer Institute. EWSR1/FLI1 Fusion Gene Type 2. NCI Thesaurus. Code C99204.

A fusion gene that results from a chromosomal translocation $\mathrm{t}(11 ; 22)(\mathrm{q} 24 ; \mathrm{q} 12)$ which fuses the first seven exons of the EWSR1 gene with exon 5 of the FLI1 gene. This rearrangement is associated with Ewing tumor/peripheral primitive neuroectodermal tumor. 